\title{
Inhibitory Effects of Osemozotan, a Serotonin 1A-Receptor Agonist, on Methamphetamine-Induced c-Fos Expression in Prefrontal Cortical Neurons
}

\author{
Rie Tsuchida, ${ }^{a, \#}$ Masahiro Kubo,,${ }^{a, \#}$ Norihito Shintani, ${ }^{a}$ Michikazu Abe, ${ }^{b}$ Katalin Köves, ${ }^{c}$ \\ Kazuki Uetsuki, ${ }^{a}$ Mariko Kuroda, ${ }^{a}$ Hitoshi Hashimoto, ${ }^{a, d}$ and Akemichi BabA ${ }^{*, a}$ \\ ${ }^{a}$ Laboratory of Molecular Neuropharmacology, Graduate School of Pharmaceutical Sciences, Osaka University; ${ }^{d}$ Center \\ for Child Mental Development, Graduate School of Medicine, Osaka Univeersity; Suita, Osaka 565-0871, Japan: \\ ${ }^{b}$ Pharmacology Department IV, Mitsubishi Tanabe Pharma Co.; Yokohama 227-0033, Japan: and ${ }^{c}$ Department of Human \\ Morphology and Developmental Biology, Faculty of Medicine, Semmelweis University; Budapest 1094, Hungary. \\ Received October 31, 2008; accepted December 13, 2008
}

Psychostimulants induce hyperlocomotion in normal subjects, although, they are effective in producing a calming effect in hyperactive subjects. This paradoxical effect has been related to changes in serotonin (5-HT) neurotransmission in hyperactive dopamine transporter-knockout mice. In addition, we observed that hyperlocomotion in mice lacking pituitary adenylate cyclase-activating polypeptide was attenuated by amphetamine dependent on 5-HT $\mathrm{HA}_{1 \mathrm{~A}}$ receptor signaling and that amphetamine, when co-administered with a 5- $\mathrm{HT}_{1 \mathrm{~A}}$ agonist, pro-

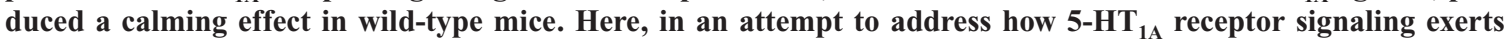
the calming action of psychostimulants, we examined c-Fos expression in several brain regions after administration of methamphetamine and osemozotan, a selective $5-\mathrm{HT}_{1 \mathrm{~A}}$ receptor agonist. The number of c-Fos-positive cells was increased in the medial prefrontal cortex, striatum and nucleus accumbens in methamphetamine (3 $\mathrm{mg} / \mathrm{kg}$ body weight)-injected mice. Osemozotan $(1 \mathrm{mg} / \mathrm{kg})$ significantly reduced the methamphetamine-induced c-Fos expression in the medial prefrontal cortex and striatum, but not in the nucleus accumbens. This osemozotan action was completely blocked by the $5-\mathrm{HT}_{1 \mathrm{~A}}$ receptor antagonist WAY-100635 $(1 \mathrm{mg} / \mathrm{kg})$. As the prefrontal cortex is considered to be involved in the beneficial actions of psychostimulant medications for attentiondeficit/hyperactivity disorder, the present result showing $5-\mathrm{HT}_{1 \mathrm{~A}}$-mediated inhibition of corticostriatal activity may partly be related to this psychostimulant action.

Key words serotonin 5- $\mathrm{HT}_{1 \mathrm{~A}}$ receptor; medial prefrontal cortex; psychostimulant; c-Fos; osemozotan; striatum

Although psychostimulants including amphetamine, methylphenidate and methamphetamine (MAMP) induce hyperlocomotion in normal subjects, they have long been recognized to have a distinct calming effect in hyperactive children, and now psychostimulants are commonly used first-line treatment of attention-deficit/hyperactivity disorder (ADHD). However, the pharmacology underpinning the treating effects of psychostimulants remains obscure. ${ }^{1-3)}$

In dopamine transporter knockout mice, it has been shown that psychostimulants such as amphetamine produce a paradoxical calming effect on locomotion and that this paradoxical effect is related to changes in serotonin (5-HT) neurotransmission. ${ }^{4)}$ Previously we demonstrated that mice lacking pituitary adenylate cyclase-activating polypeptide (PACAP), a neuropeptide with pleiotropic activities, ${ }^{5)}$ exhibit marked phenotypes including a high early mortality rate before weaning, hypophagia and leanness, as well as behavioral abnormalities, such as novelty-induced locomotor hyperactivity and intense jumping behavior. ${ }^{6-8)}$ Interestingly, the hyperactive behavior was paradoxically ameliorated by amphetamine and this antihyperkinetic effect of amphetamine was completely blocked by the 5 -HT $1 \mathrm{~A}\left(5-\mathrm{HT}_{1 \mathrm{~A}}\right)$ receptor antagonist WAY-100635. ${ }^{7)}$ In PACAP-deficient mice, c-Fos-positive neurons were increased in the prefrontal cortex compared with wild-type mice when treated with amphetamine. This observation suggests increased inhibitory control by prefrontal neurons in these mutant mice, as the prefrontal cortex is implicated in the pathophysiology of behavioral dysregulation. $^{9)}$
In an attempt to address how $5-\mathrm{HT}_{1 \mathrm{~A}}$ receptor signaling exerts the calming action of psychostimulants, in the present study, we examined c-Fos expression in several brain regions as a marker of neuronal activity to define the pattern of neurons excited after administration of MAMP and the selective $5-\mathrm{HT}_{1 \mathrm{~A}}$ receptor agonist osemozotan $(\mathrm{OSE})^{10,11)}$ in normal Institute of Cancer Research (ICR) mice.

\section{MATERIALS AND METHODS}

Animals All animal experiments were carried out in accordance with protocols approved by the Animal Research Committee of Osaka University. One hundred and twentyseven male Slc:ICR mice were obtained from Japan SLC (Shizuoka, Japan) at 6 weeks of age and were allowed to acclimate in our animal facility for at least 1 week before the initiation of experiments. All mice were housed in a temperature $\left(23 \pm 1^{\circ} \mathrm{C}\right)$ - and light-controlled room with a 12-h light/12-h dark cycle (lights on from 08:00 to 20:00) and allowed free access to water and a standard diet.

Drugs MAMP (Dainippon Pharma, Osaka, Japan) was dissolved at a concentration of $0.3 \mathrm{mg} / \mathrm{ml}$ in saline $(0.9 \%$ $\mathrm{NaCl}$ solution) and injected intraperitoneally at a dose of $3 \mathrm{mg} / \mathrm{kg}$ body weight just before the test began. OSE (previously called MKC-242 and also known as MN-305; $(S)-5-[3-$ [(1,4-benzodioxan-2-ylmethyl)amino]propoxy]-1,3-benzodioxole $\mathrm{HCl}$; Mitsubishi Tanabe Pharma Co., Yokohama, Japan) was suspended at a concentration of $0.1 \mathrm{mg} / \mathrm{ml}$ in $0.5 \%$ carboxymethylcellulose (Nakalai Tesque, Kyoto, Japan) 
and injected intraperitoneally at a dose of $1 \mathrm{mg} / \mathrm{kg}$ body weight $10 \mathrm{~min}$ before the test. WAY100635 ( $N$-(2-[4-(2methoxyphenyl)-1-piperazinyl]ethyl)- $N$-(2-pyridinyl)cyclohexanecarboxamide; Sigma-Aldrich Inc., Tokyo, Japan) was dissolved at a concentration of $0.2 \mathrm{mg} / \mathrm{ml}$ in saline and injected subcutaneously at a dose of $1 \mathrm{mg} / \mathrm{kg}$ body weight before the test began.

Immunohistochemistry Two hours after drugs were injected, mice were deeply anesthetized with pentobarbital ( $40 \mathrm{mg} / \mathrm{kg}$ intraperitoneally), perfused transcardially with saline followed by paraformaldehyde $(4 \%)$ in phosphatebuffered saline $(0.1 \mathrm{M})$. Frontal sections $(20 \mu \mathrm{m})$ containing the medial prefrontal cortices (prelimbic cortex and infralimbic cortex) at $+1.42 \mathrm{~mm}$ from the bregma, the dorsomedial striatum at $+1.10 \mathrm{~mm}$ from the bregma, and the nucleus accumbens at $+0.98 \mathrm{~mm}$ from the bregma ${ }^{12)}$ were dissected and processed for immunohistochemistry with anti-c-Fos rabbit polyclonal primary antibody (Santa Cruz Biotechnology, Santa Cruz, CA, U.S.A.; diluted 1:2000) and fluorescein isothiocyanate (FITC)-conjugated donkey secondary anti-rabbit immunoglobulin G (IgG) antibody (Jackson ImmunoResearch, West Grove, PA, U.S.A.; diluted 1 : 500). For c-Fos and neuronal nuclei $(\mathrm{NeuN})$ or parvalbumin double staining, the sections were immunostained with the anti-cFos antibody (above) together with either anti-NeuN mouse monoclonal antibody (Santa Cruz Biotechnology; diluted $1: 2000)$ or anti-parvalbumin mouse monoclonal antibody (Sigma-Aldrich; diluted 1:2000). The same fluorescein isothiocyanate (FITC)-conjugated donkey secondary antirabbit immunoglobulin $\mathrm{G}$ (IgG) antibody mentioned above and Alexa Fluor 594-conjugated goat secondary anti-mouse IgG antibody (Molecular Probes, Eugene, OR, U.S.A.; diluted $1: 500)$ were used for visualization of c-Fos, NeuN and parvalbumin. Hoechst 33258 (Jackson ImmunoResearch; $1: 1000$ ) was also used to stain cell nuclei. c-Fos-positive nuclei were counted manually by experienced observers blinded to the treatment.

Statistical Analysis The statistical significance of differences was assessed using ANOVA, followed by post-hoc Fisher's least significance difference tests. Statistical significance was defined as $p<0.05$. All values are expressed as mean \pm S.E.M.

\section{RESULTS}

OSE-Induced Decrease in the Number of c-Fos-Positive Cells Induced by MAMP in the Medial Prefrontal Cortex and Striatum c-Fos expression was examined in the medial prefrontal cortex, striatum and nucleus accumbens $2 \mathrm{~h}$ after administration of $3 \mathrm{mg} / \mathrm{kg}$ body weight of MAMP together with or without $1 \mathrm{mg} / \mathrm{kg}$ of OSE (Fig. 1). The number of c-Fos-positive cells was increased by $3 \mathrm{mg} / \mathrm{kg}$ MAMP in the three regions tested (Figs. 1a, c, f). Although OSE alone did not change the number of c-Fos-positive cells, it significantly decreased the number of c-Fos-positive cells induced by MAMP in the medial prefrontal cortex and striatum (Figs. 1a, d, g). However, OSE had no effect on either basal or MAMP-induced increase in the number of c-Fos-positive cells in the nucleus accumbens.

The Selective 5-HT ${ }_{1 \mathrm{~A}}$ Antagonist WAY-100635 Blocks the Inhibitory Effect of OSE on MAMP-Induced Increase
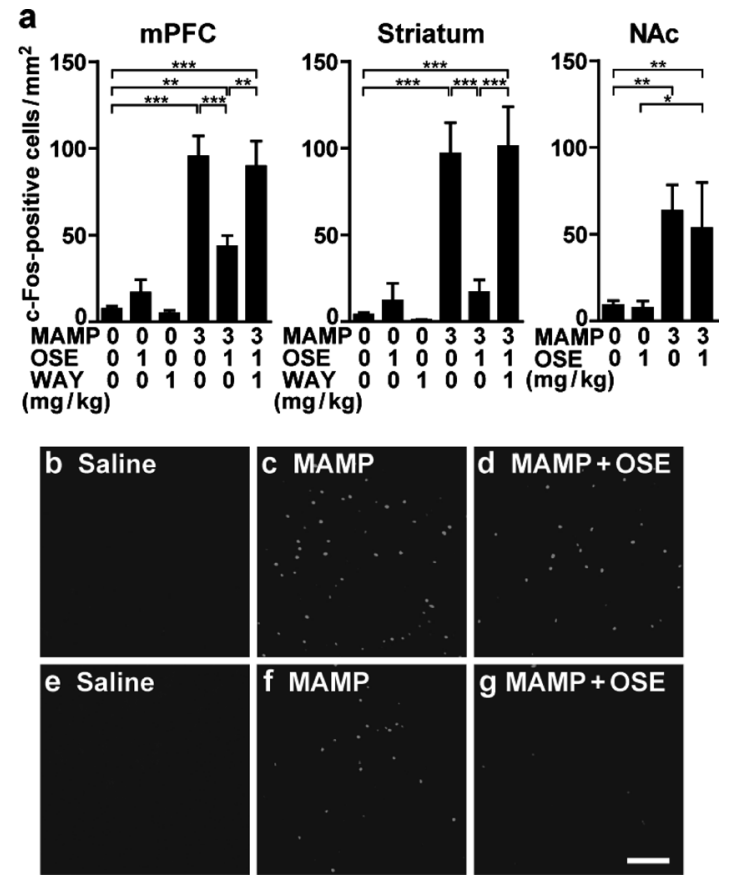

Fig. 1. c-Fos-Positive Neurons in the Medial Prefrontal Cortex (mPFC), Striatum, and Nucleus Accumbens (NAc) in Mice That Received MAMP, OSE and/or WAY-100635

(a) Number of c-Fos-positive neurons in mice that received the indicated doses of MAMP, OSE and/or WAY-100635 (WAY). $n=6-11$ per group. (b-g) Photomicrographs of staining for c-Fos in $\mathrm{mPFC}(\mathrm{b}-\mathrm{d})$ and striatum $(\mathrm{e}-\mathrm{g})$ of mice that received saline (b, e), MAMP (3 mg/kg)(c, f), and MAMP (3 mg/kg) plus OSE $(1 \mathrm{mg} / \mathrm{kg})(\mathrm{d}, \mathrm{g})$. Scale bar, $100 \mu \mathrm{m}$, common to (b-f). $* p<0.05$, $* * p<0.01$, $* * * p<0.001$

in the Number of c-Fos-Positive Cells The inhibitory effects of OSE on the MAMP-induced increase in the number of c-Fos-positive cells in the medial prefrontal cortex and striatum was completely blocked by WAY-100635 (1 mg/kg) (Fig. 1a). WAY-100635 alone did not change the number of c-Fos-positive cells, suggesting that endogenous activation of $5-\mathrm{HT}_{1 \mathrm{~A}}$ receptors did not significantly contribute to c-Fos expression in the present conditions.

Double-Immunohistochemical Study in the Medial Prefrontal Cortex To define the cell types responsible for the inhibitory effects of OSE, we conducted a double-immunohistochemical study in the medial prefrontal cortex (Fig. 2). In MAMP-injected mice, c-Fos-positive cells were also NeuN positive (Figs. $2 \mathrm{a}-\mathrm{d}$ ), but were parvalbumin negative (Figs. 2e-h). The number of cells positive for c-Fos and NeuN were remarkably reduced by co-administration of MAMP and OSE (Fig. 2i).

\section{DISCUSSION}

In the present study, we examined c-Fos expression and showed that OSE significantly decreased the number of cFos-positive cells induced by MAMP in the medial prefrontal cortex. In addition, in the striatum but not in the nucleus accumbens, the MAMP-induced increase in the number of cFos-positive cells was greatly reduced by OSE. We have recently demonstrated that OSE when co-administered with MAMP exerts a marked calming effect in mice (submitted elsewhere). These observations suggest that OSE-mediated inhibition of corticostriatal activity may be involved in the 5$\mathrm{HT}_{1 \mathrm{~A}}$ agonist-induced antihyperkinetic effects when co-ad- 


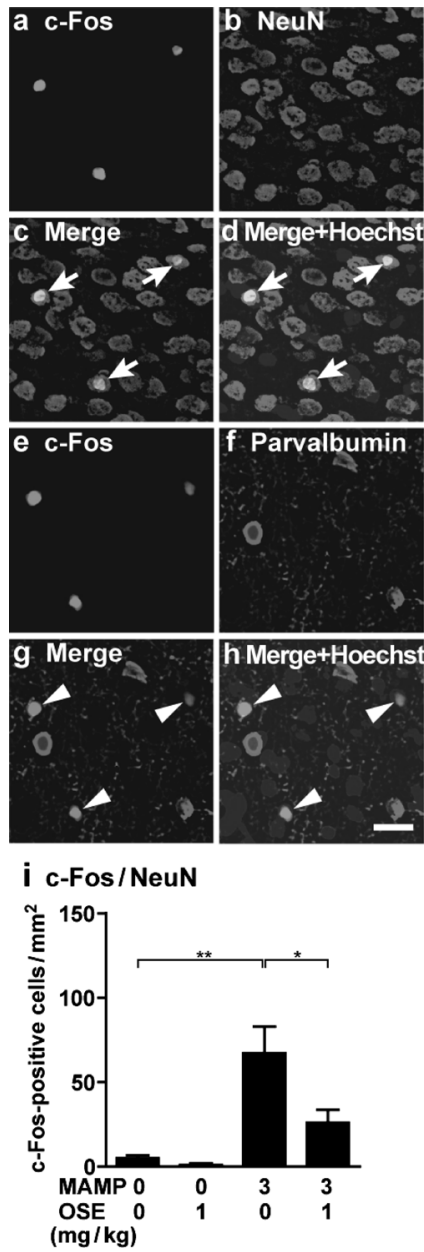

Fig. 2. Double-Staining for c-Fos with NeuN or Parvalbumin

$(\mathrm{a}-\mathrm{h})$ Photomicrographs of double staining for c-Fos with NeuN $(\mathrm{a}-\mathrm{d})$ or parvalbumin $(\mathrm{e}-\mathrm{h})$ in the medial prefrontal cortex of mice that received MAMP $(3 \mathrm{mg} / \mathrm{kg})$ Scale bar, $20 \mu \mathrm{m}$, common with $(\mathrm{a}-\mathrm{g})$. Hoechst, Hoechst 33258; arrows, c-Fos and NeuN double-labeled cells; arrowheads, c-Fos single-labeled cells. (i) Number of cells positive for both c-Fos and NeuN in mice that received the indicated doses of MAMP and/or OSE. $n=4-8$ per group. $* p<0.05, * * p<0.01$.

ministered with psychostimulants in mice and the beneficial effects of psychostimulants in hyperactivity disorders.

Here we employed MAMP $(3 \mathrm{mg} / \mathrm{kg})$ to induce c-Fos expression, which is a rather high dose of the drug. However, we confirmed that MAMP (1 mg/kg) significantly increased the number of c-Fos-positive cells, and that this increase tended to be reduced by OSE ( $1 \mathrm{mg} / \mathrm{kg}$ ) (unpublished data). We examined c-Fos expression $2 \mathrm{~h}$ after drug injection, although the antihyperkinetic effects of 5- $\mathrm{HT}_{1 \mathrm{~A}}$ agonists co-administered with psychostimulants were observed as early as $10 \mathrm{~min}$ after drug injection. Because the number of c-Fospositive cells at early time points (for example, $30 \mathrm{~min}$ or $1 \mathrm{~h}$ ) was small, and sometimes close to that of the vehicle-treated group, we sacrificed the animals $2 \mathrm{~h}$ after drug injection. The c-Fos expression at that time should reflect the neuronal activation (or its inhibition) that occurs soon after drug injection.

In the medial prefrontal cortex, most c-Fos-positive cells were defined as NeuN-positive and parvalbumin-negative neurons that are likely pyramidal principal neurons, but not GABAergic interneurons. This result suggests that the stimulation of $5-\mathrm{HT}_{1 \mathrm{~A}}$ receptors expressed in GABAergic neurons in the prefrontal cortex ${ }^{13)}$ may not be involved in the ob- served antihyperkinetic effects. In support of this, we obtained data that GABA receptor inhibitors (flumazenil and bicuculline) did not affect the antihyperkinetic effects of OSE co-administered with psychostimulants (data not shown).

Since it has been demonstrated that c-fos mRNA expression is greatly increased by exposure to environmental novelty and this effect is not further increased by amphetamine in the frontal cortex, ${ }^{14)}$ we also examined the effects of a 5$\mathrm{HT}_{1 \mathrm{~A}}$ agonist on the c-Fos expression induced by novelty and found that the number of c-Fos-positive cells tended to decrease (unpublished data).

Gainetdinov and coworkers proposed that hyperkinetic behavior might be controlled through precise targeting of 5-HT receptors. ${ }^{4)}$ In support of this idea, it has been shown that 5$\mathrm{HT}_{1 \mathrm{~A}}$ agonists can attenuate psychostimulant-induced behavioral sensitization and increases in locomotor activity. ${ }^{15-18)}$ The prefrontal cortex is considered to be involved in the beneficial actions of psychostimulant medications for $\mathrm{ADHD}^{1-3)}$ and dysregulation of this brain region has been postulated to lead to disinhibition in targets of the prefrontal cortex projection. ${ }^{9}$ In hyperkinetic PACAP-deficient mice, we recently demonstrated that: 1) amphetamine-induced c-Fos expression was enhanced specifically in the prefrontal cortex; and 2) the antihyperkinetic effects of amphetamine were completely blocked by the 5-HT ${ }_{1 \mathrm{~A}}$ antagonist WAY-100635. ${ }^{7)}$ The present results, taken together with those of earlier studies, indicate that $5-\mathrm{HT}_{1 \mathrm{~A}}$-mediated inhibition of prefrontal and corticostriatal activity may be at least partly related to the beneficial actions of psychostimulant medications for ADHD.

Acknowledgments This work was supported in part by Grants-in-Aid for Scientific Research from the Japan Society for the Promotion of Science (JSPS). This work was also supported in part by grants from the Japan-France Integrated Action Program (SAKURA) funded by JSPS and the Ministère des Affaires Etrangères in France (MAE); Uehara Memorial Foundation; Senri Life Science Foundation; Public Health Research Foundation; Taisho Pharmaceutical Co., Ltd.; and Mitsubishi Tanabe Pharma Co.

\section{REFERENCES}

1) Solanto M. V., Behav. Brain Res., 130, 65-71 (2002).

2) Wilens T. E., Biederman J., Spencer T. J., Annu. Rev. Med., 53, 113 131 (2002).

3) Andersen S. L., Trends Pharmacol. Sci., 26, 237-243 (2005).

4) Gainetdinov R. R., Wetsel W. C., Jones S. R., Levin E. D., Jaber M., Caron M. G., Science, 283, 397-401 (1999).

5) Vaudry D., Gonzalez B. J., Basille M., Yon L., Fournier A., Vaudry H., Pharmacol. Rev., 52, 269-324 (2000).

6) Hashimoto H., Shintani N., Tanaka K., Mori W., Hirose M., Matsuda T., Sakaue M., Miyazaki J., Niwa H., Tashiro F., Yamamoto K., Koga K., Tomimoto S., Kunugi A., Suetake S., Baba A., Proc. Natl. Acad. Sci. U.S.A., 98, 13355-13360 (2001).

7) Tanaka K., Shintani N., Hashimoto H., Kawagishi N., Ago Y., Matsuda T., Hashimoto R., Kunugi H., Yamamoto A., Kawaguchi C., Shimada T., Baba A., J. Neurosci., 26, 5091-5097 (2006).

8) Tomimoto S., Ojika T., Shintani N., Hashimoto H., Hamagami K., Ikeda K., Nakata M., Yada T., Sakurai Y., Shimada T., Morita Y., Ishida C., Baba A., J. Pharmacol. Sci., 107, 41-48 (2008).

9) Goldman-Rakic P. S., Muly E. C. 3rd, Williams G. V., Brain Res. Brain Res. Rev., 31, 295-301 (2000).

10) Matsuda T., Yoshikawa T., Suzuki M., Asano S., Somboonthum P., Takuma K., Nakano Y., Morita T., Nakasu Y., Kim H. S., Jpn. J. Phar- 
macol., 69, 357-366 (1995).

11) Abe M., Tabata R., Saito K., Matsuda T., Baba A., Egawa M., J. Pharmacol. Exp. Ther., 278, 898-905 (1996).

12) Franklin K. B. J., Paxinos G., "The Mouse Brain in Stereotaxic Coordinates," Academic Press, San Diego, 1997.

13) Santana N., Bortolozzi A., Serrats J., Mengod G., Artigas F., Cereb. Cortex, 14, 1100-1109 (2004).

14) Badiani A., Oates M. M., Day H. E., Watson S. J., Akil H., Robinson
T. E., J. Neurosci., 18, 10579-10593 (1998).

15) Przegalinski E., Filip M., Behav. Pharmacol., 8, 699-706 (1997).

16) Przegalinski E., Siwanowicz J., Baran L., Filip M., Life Sci., 66, 1011-1019 (2000).

17) Ago Y., Nakamura S., Uda M., Kajii Y., Abe M., Baba A., Matsuda T., Neuropharmacology, 51, 914-922 (2006).

18) Ago Y., Nakamura S., Baba A., Matsuda T., J. Pharmacol. Sci., 106, $15-21$ (2008). 